\title{
ГРАНУЛИРОВАННЫЙ КАЛИЙ КАРБОНАТ В РАЦИОНАХ ТЕЛЯТ
}

\author{
А.Н. Бетин (фото) \\ к.С.-х.н., ведущий научный сотрудник лаборатории \\ технологии производства свинины \\ А.И. Фролов \\ К.С.-Х.Н., ведущий научный сотрудник лаборатории \\ технологии производства молока и говядины \\ ФГБНУ «Всероссийский научно-исследовательский институт \\ использования техники и нефтепродуктов в сельском \\ хозяйстве», г. Тамбов
}

При разработке рационов кормления для молодняка крупного рогатого скота важно уделять особое внимание минеральным веществам, из которых наибольшее значение имеют кальций, фосфор, калий, магний, марганец, цинк, кобальт, йод, железо, медь. Учитывая жизненную необходимость использования минеральных кормовых добавок, разработка и применение новых препаратов, позволяющих обеспечить биологическую защиту организма, весьма актуальна [1, 2].

Одним из ключевых элементов является калий, который должен поступать в организм животного ежедневно с кормами, поскольку сохраняется в теле короткое время, и его роль важна, так как он является донором катионов. Калий включается в осмотическое давление и кислотно-щелочное регулирование, водный баланс, передачу нервных импульсов, сокращение мышц, транспортировку кислорода и двуокиси углерода, фосфолирование креатинина, активирование пируваткиназы, как активатора во многих ферментных реакциях, при поглощении аминокислот и синтезе протеина, обмене углеводов и поддержании в норме сердечной и почечной ткани.

Целью исследований явилось изучение влияния различных норм минеральной добавки гранулированного калия карбоната в комбикорм на физиологическое состояние телят, их продуктивность и экономическую эффективность выращивания.

\section{Методика исследования}

Эксперимент был проведён в два этапа на молодняке в возрасте от 2-х до 4-х и от 4-х до 6-ти месяцев по следующим схемам (табл. 1, 2).

В опытах изучали изменение живой массы и среднесуточного прироста телят, поведение, биохимические показатели крови, состояние желудочно-кишечного тракта по показателям бактериологического и копрологического исследования фекалий, экономическую эффективность выращивания.

Телят в группы подбирали по принципу аналогов с учётом живой массы, состояния здоровья [3]. Кормление осуществлялось по научно обоснованным нормам $[4,5,6]$. 
Таблица 1 - Схема первого этапа эксперимента (2-месячные телята)

\begin{tabular}{|l|c|c|c|}
\hline \multicolumn{1}{|c|}{ Группа } & $\begin{array}{c}\text { Количество } \\
\text { животных, гол. }\end{array}$ & $\begin{array}{c}\text { Живая масса } \\
\text { при постановке, кг }\end{array}$ & Условия кормления \\
\hline 1 - контрольная & 10 & $60-65$ & Основной рацион (ОР) \\
\hline 2 - опытная & 10 & $60-65$ & ОР + 1 кг калия карбоната на 1 т комбикорма \\
\hline 3 - опытная & 10 & $60-65$ & ОР + 2 кг калия карбоната на 1 т комбикорма \\
\hline
\end{tabular}

\section{Результаты исследования}

В результате исследования установлено, что при выращивании телят от 2- до 4-месячного возраста (табл. 3) среднесуточный прирост живой массы у телят опытных групп превышал на 13 и 20 г по сравнению с контрольной группой (715 и 722 г против 702 г), что на 1,9-2,8\% выше, чем в контрольной группе. Включение калия карбоната на 1 кг в составе комбикорма повлияло положительно на увеличение живой массы телят за период проведения опыта на 0,8 и 1,2 кг, или на $1,9-2,8 \%$, по сравнению с контрольной группой.
Результаты исследований крови показали, что содержание общего белка, глюкозы, кальция, фосфора и калия в крови у телят всех подопытных групп было в пределах физиологической нормы. Однако содержание общего белка, глюкозы, кальция и фосфора в сыворотке крови у животных 2 и 3 опытных групп по сравнению с телятами контрольной было больше на 2,56 и 4,0\%, 6,7 и $8,9 \%, 8,0-10,7 \%, 7,1-8,6 \%$ соответственно.

По концентрации калия, который является необходимым элементом для поддержания осмотического давления, регуляции реакции крови

Таблица 2 - Схема второго этапа эксперимента (4-месячные телята)

\begin{tabular}{|l|c|c|c|}
\hline \multicolumn{1}{|c|}{ Группа } & $\begin{array}{c}\text { Количество } \\
\text { животных, гол. }\end{array}$ & $\begin{array}{c}\text { Живая масса при } \\
\text { постановке, кг }\end{array}$ & Условия кормления \\
\hline 1 - контрольная & 10 & $110-115$ & Основной рацион (ОР) \\
\hline 2 - опытная & 10 & $110-115$ & ОР + 2 кг калия карбоната на 1 т комбикорма \\
\hline 3 - опытная & 10 & $110-115$ & ОР + 4 кг калия карбоната на 1 т комбикорма \\
\hline
\end{tabular}

и тканевой жидкости, вышеуказанные группы телят превосходили контрольных животных на 5,5 и 9,3\%. Увеличение глюкозы и кальция в сыворотке крови объясняется применением калия карбоната, способствующего повышению степени использования изучаемых элементов из рационов, что подтверждается повышением продуктивности опытных телят.

Анализ содержания ЖКТ у животных всех групп в изучаемый возрастной период установил, что консистенция, форма, цвет и запах практически были одинаковые. Показатель рH 5,22-5,23 (слабокислая среда), примеси (кишечные паразиты и др.) отсутствовали, из чего следует, что секреторная и всасывающая функция желудочнокишечного тракта у телят всех подопытных групп были нормальными.

В 4-месячном возрасте микробиоценозы телят опытных и контрольной групп соответствовали физиологической норме по количественному

Таблица 3 - Продуктивность подопытных телят (2-4 мес.)

\begin{tabular}{|c|c|c|c|c|c|c|}
\hline \multirow[b]{2}{*}{ Группа } & \multirow{2}{*}{$\begin{array}{c}\text { Живая масса } \\
\text { при } \\
\text { постановке, } \\
\text { кг }\end{array}$} & \multirow{2}{*}{$\begin{array}{c}\text { Живая масса } \\
\text { в конце } \\
\text { опыта, кг }\end{array}$} & \multirow[b]{2}{*}{$\begin{array}{l}\text { Прирост жи- } \\
\text { вой массы, кг }\end{array}$} & \multirow{2}{*}{$\begin{array}{l}\text { Средне- } \\
\text { суточный } \\
\text { прирост, г }\end{array}$} & \multicolumn{2}{|c|}{ Разница } \\
\hline & & & & & $\begin{array}{c}\text { по живой } \\
\text { массе, \% }\end{array}$ & $\begin{array}{c}\text { по средне- } \\
\text { суточному } \\
\text { приросту, \% }\end{array}$ \\
\hline 1 - контрольная & $62,2 \pm 0,16$ & $104,3 \pm 0,28$ & $42,1 \pm 0,28$ & $702 \pm 4,26$ & 100,0 & 100,0 \\
\hline 2 - опытная & $62,3 \pm 0,19$ & $105,2 \pm 0,21$ & $42,9 \pm 0,28$ & $715 \pm 4,70$ & 101,9 & 101,9 \\
\hline 3 - опытная & $63,1 \pm 0,52$ & $106,4 \pm 0,26$ & $43,3 \pm 0,54$ & $722 \pm 9,09$ & 102,8 & 102,8 \\
\hline
\end{tabular}


и качественному содержанию облигатных микроорганизмов. Однако по содержанию факультативной микрофлоры и условно-патогенных бактерий микробиоценоз контрольных животных выходил за рамки нормы.

У телят, получавших к основному рациону калия карбоната, суммарное количество актов жвачки, зафиксированное в 10-минутном интервале в течение суток (общий суммарный жвачный период) по сравнению с контрольными было больше на 2,7 и 2,4 соответственно, что связано, по-видимому, с особенностью пищеварения у молодняка, получавшего к основному рациону калия карбоната.

Следует отметить, что количество актов стояния и лежания у молодняка второй и третьей опытных групп, в сравнении с контрольной, было в целом меньше на 9,2 и 8,2\% соответственно. В количестве актов приёма воды различий практически не установлено. В то же время у телят второй и третьей опытных групп по отношению к контрольной актов приёма корма зафиксировано больше соответственно на 1,08 и 2,16\%.

При расчёте экономической эффективности установлено, что при стоимости 125 рублей за 1 кг живой массы можно дополнительно получить соответственно 100 и 150 рублей денежной выручки от реализации каждого опытного животного. Затраты на израсходованный препарат составили 13,75 и 27,5 рублей, в результате в опытных группах животных будет получено чистого дополнительного дохода в расчёте на 1 голову 86,25 и 122,5 рублей соответственно.

По результатам второго эксперимента на телятах от 4- до 6-месячного возраста установлено (табл. 4), что среднесуточный прирост живой массы у телят опытных групп, получавших в составе рациона кормовую добавку калия карбоната, составил 775 и 785 г, что на 3,1 и 4,4\% выше, чем в контрольной группе. Более высокая интенсивность роста опытных животных привела к опере- жению сверстников из контрольной группы по живой массе в среднем на 1,4 и 2 кг, или на 3,1 и 4,4\%, при близкой достоверности различий между группами.

Анализ фекалий у животных всех групп в изучаемый возрастной период показал, что консистенция, форма, цвет и запах практически были одинаковые, примеси (кишечные паразиты и др.) отсутствовали.

В возрасте 180 суток у опытных и контрольных телят в образцах кала выявлено одинаковое и высокое содержание представителей нормальной микрофлоры. Содержание энтерококков в образцах животных всех групп было в пределах нормы. Количество стафилококков в образцах кала опытных телят 2-й и 3-й групп было в допустимых пределах, а у контрольных превысило норму на 1 разведение, или на 1 порядок (в 10 раз). Дрожжевые и плесневые грибы в образцах кала телят контрольной и опытных групп не обнаружены. В образцах контрольной группы в высоких титрах $10^{6} \mathrm{KOE} / г$ обнаружены гемолитические E.coli и $10^{5} \mathrm{KOE} / г$ неферментирующие глюкозу свободноживущие сапрофитирующие грамнегативные бактерии. Патогенные бактерии рода Salmonella в образцах молодняка всех групп не обнаружены.

У животных обеих опытных групп по отношению к телятам контрольной группы содержание в сыворотке крови общего белка было больше на 5,7 и 9,1\% соответственно. Такая же тенденция наблюдалась и по концентрации глюкозы, которая составила у телят этих групп 3,09 и 3,45 ммоль/л, что больше, чем у контрольных, на 11,9 и 25\% соответственно. Содержание кальция и фосфора в сыворотке телят опытных групп превышало показатели аналогов из контрольной группы на 4,4-7,3\% и 7,5-10,2\% соответственно.

В опытных группах, по сравнению с контрольными животными, получено больше дополнительного дохода от условной реализации каждого жи-

Таблица 4 - Продуктивность подопытных телят (4-6 мес.)

\begin{tabular}{|c|c|c|c|c|c|c|}
\hline \multirow[b]{2}{*}{ Группа } & \multirow[b]{2}{*}{$\begin{array}{c}\text { Живая масса } \\
\text { при постанов- } \\
\text { ке, кг }\end{array}$} & \multirow[b]{2}{*}{$\begin{array}{c}\text { Живая масса } \\
\text { в конце опы- } \\
\text { та, кг }\end{array}$} & \multirow[b]{2}{*}{$\begin{array}{l}\text { Прирост жи- } \\
\text { вой массы, кг }\end{array}$} & \multirow[b]{2}{*}{$\begin{array}{c}\text { Среднесуточ- } \\
\text { ный прирост, } \\
\text { г }\end{array}$} & \multicolumn{2}{|c|}{ Разница } \\
\hline & & & & & $\begin{array}{c}\text { по живой } \\
\text { массе, \% }\end{array}$ & $\begin{array}{c}\text { по средне- } \\
\text { суточному } \\
\text { приросту, \% }\end{array}$ \\
\hline 1 - контрольная & $110,4 \pm 0,46$ & $155,5 \pm 0,38$ & $45,1 \pm 0,65$ & $752 \pm 7,65$ & 100,0 & 100,0 \\
\hline 2 - опытная & $110,3 \pm 0,43$ & $156,8 \pm 0,32$ & $46,5 \pm 0,37$ & $775 \pm 6,16$ & 103,1 & 103,1 \\
\hline 3 - опытная & $110,4 \pm 0,32$ & $157,5 \pm 0,33$ & $47,1 \pm 0,50$ & $785 \pm 8,96$ & 104,4 & 104,4 \\
\hline
\end{tabular}


вотного на 164,44 и 228,88 рублей с учётом вычета 10,56 и 21,12 рублей стоимости кормовой добавки.

\section{Bыводы}

Таким образом, минеральная кормовая добавка гранулированного калия карбоната оказывает положительное влияние на биохимические показатели крови опытных телят, увеличивая уровень глюкозы в крови, активизирует белковый обмен и нормализует его фракционный состав. Обогащение рациона кормовой добавкой калия карбоната способствует повышению в крови животных содержания показателей минеральных веществ - кальция, фосфора и калия.

Скармливание гранулированного калия карбоната в рационах молодняка крупного ро- гатого скота в возрасте 2-4 мес. в дозе 1 и 2 кг на 1 т комбикорма увеличивает живую массу за 60 дней применения кормовой добавки на 0,8 и 1,2 кг, или на 1,9 и 2,8\%, а среднесуточный прирост - на 13 и 20 г, или на 1,9 и 2,8\%. Использование кормовой добавки телятам от 4-х до 6-ти месяцев при норме 2 кг и 4 кг на 1 т концентратов увеличило живую массу и среднесуточный прирост соответственно на 1,4 и 2 кг и 23 и 33 г, или на 3,1 и 4,4\%.

Дополнительный чистый доход от условной реализации каждого животного в опытной группе телят от 2- до 4-месячного и от 4- до 6-месячного возраста, по сравнению с контролем, составил в среднем соответственно 86,25-122,5 и 164,44228,88 рублей на 1 голову.

\section{תuтература}

1. Иванова, О.В. Применение комплексной природной добавки в кормлении свиней [Текст] / О.В. Иванова // Свиноводство. - 2015. - № 4. - С. 49-51.

2. Никанова, Л.А. Сравнительное изучение природных кормовых добавок при откорме свиней [Текст] / Л.А. Никанова, Ю.П. Фомичёв, Д.Ф. Рындина // Ветеринария и кормление. - 2011. - № 4. - С. 28-30.

3. Викторов, П.И. Методика и организация зоотехнических опытов [Текст] / П.И. Викторов, В.К. Менькин. - М.: Агропромиздат, 1991. - 112 с.: ил. - (Учебники и учеб. пособия для студентов высш. учеб. заведений).

4. Калашников, А.П. Нормы и рационы кормления сельскохозяйственных животных [Текст]: справочное пособие / А.П. Калашников, В.И. Фисин и др. - М., 2003. - С. 84-85.

5. Нормы потребностей молочного скота в питательных веществах в США [Текст] / пер. седьмого издания NRC 2001 г. с англ. Н.Г. Первов, Н.А. Смекалов. - М., 2007. - С. 133, 289.

6. Рекомендации по детализированному кормлению молочного скота [Текст]: справочное пособие. Дубровицы: Изд-во ВИЖ им. Л.К. Эрнста, 2016. - С. 20-21.

\section{References}

1. Ivanova, O.V. Primenenie kompleksnoj prirodnoj dobavki v kormlenii svinej [Tekst] / O.V. Ivanova // Svinovodstvo. - 2015. - № 4. - S. 49-51.

2. Nikanova, L.A. Sravnitel'noe izuchenie prirodnyh kormovyh dobavok pri otkorme svinej [Tekst] / L.A. Nikanova, Yu.P. Fomichev, D.F. Ryndina // Veterinarija i kormlenie. - 2011. - № 4. - S. 28-30.

3. Viktorov, P.I. Metodika i organizacija zootehnicheskih opytov [Tekst] / P.I. Viktorov, V.K. Men'kin. - M.: Agropromizdat, 1991. - 112 s.: il. - (Uchebniki i ucheb. posobija dlja studentov vyssh. ucheb. zavedenij).

4. Kalashnikov, A.P. Normy i raciony kormlenija sel'skohozjajstvennyh zhivotnyh [Tekst]: spravochnoe posobie / A.P. Kalashnikov, V.I. Fisin i dr. - M., 2003. - S. 84-85.

5. Normy potrebnostej molochnogo skota v pitatel'nyh veshhestvah v SShA [Tekst] / per. sed'mogo izdanija NRC 2001 g. s angl. N.G. Pervov, N.A. Smekalov. - M., 2007. - S. 133, 289.

6. Rekomendacii po detalizirovannomu kormleniju molochnogo skota [Tekst]: spravochnoe posobie. Dubrovicy: Izd-vo VIZh im. L.K. Ehrnsta, 2016. - S. 20-21. 